\title{
STATISTICAL ANALYSIS OF THE EFFECT OF THE USE OF LIBRARY ON THE ACADEMIC PERFORMANCE OF STUDENTS IN EKITI STATE, NIGERIA
}

\author{
Olubiyi Adenike Olufunmilola ${ }^{1}$, \\ Babalola Bayowa Teniola ${ }^{2 i}$, \\ Fadugba Sunday Emmanuel ${ }^{3}$ \\ ${ }^{1}$ Department of Statistics, \\ Ekiti State University, \\ Ado Ekiti, Nigeria \\ ${ }^{2}$ Department of Mathematics and Statistics, \\ Kampala International University, \\ Kampala, Uganda \\ ${ }^{3}$ Department of Mathematics, \\ Ekiti State University, \\ Ado Ekiti, Nigeria
}

\begin{abstract}
:
This study examines perceptions of university library usage in considering factors that influence achievement of students and academic performance. A thorough review of relevant literature examined approaches to determining user satisfaction of students and factors that influence library usage. Data was gotten from students in three different tertiary institutions in Ekiti State, Nigeria. The result shows that the use of library has positive effect on the academic performance of students.
\end{abstract}

Keywords: institutions, library, academic performance, students

\section{Introduction}

A library is a collection of sources of information and similar resources, made accessible to a defined community for reference or borrowing. It provides physical and digits access to material, and maybe a physical building or room, or a virtual space, or both. A library's collection can include books, periodicals, newspaper, manuscripts, films, maps, print, documents microform, CDs, cassettes, videotapes, DVDs, Blu-ray Discs, e-books, audio books, databases, and other formats. Libraries range in size. From a shelf of books to several million items. A library is organised for use and maintained by public body, an

i Correspondence: email teniola.babalola@eksu.edu.ng 
institution, a corporation, or a private individual (Adeyemi (2010), Busayo (2014), Esse (2014)).

One of the fundamental laws of the library is that the resources-books and nonbook must be well consulted. The librarian has to acquire and provide access to the information stocked in the library. The user is very important in the practice of librarianship; this is because library process revolves around the users. The user is very critical to the services of a library, hence the user of a library must be constantly asked to assess the services and resources provided, as this will help the library to improve upon its services. No matter how large the stock of a library is, if the services and its resources are not fully utilized, such a library will end up a white elephant. It is worthy to note however that any attempt on the part of the library to ignore the satisfaction of its users will be done at the library's peril (Budd (1998), Jackson (2003)).

The primary purpose of any library is to support the students with the provision of adequate and current information and material in order to support the academic curriculum. With the growth in library collections, and technological advancement in information handling and retrieving techniques, it is necessary to guide students and other library users on the accessibility and retrieval of those information resources. In order to ensure that students have the intellectual abilities and skills to retrieve information as well as construct a framework for learning, the university library makes provision for library instruction, which is also referred to as user education, instructional program, teaching the use of library and Information sources among others (Alan (2002); Benbasat (1984)).

A library's fundamental purpose has always been to support the process of research and education by helping users find information and ascertain its value. In any academic institution, it is expected that the library should provide opportunities for librarians to serve users in different ways. For example, by providing more in-depth consultation to research questions or hosting new types of tool that enable users to guide themselves in specialized disciplines. The demonstrable value of academic libraries and their staff must increasingly reside in the guidance they provide as well as the technical infrastructures they develop and maintain. Furthermore, the library performs the role of enhancing the creation of new academic communities on campus. One of the most vital advantages of an academic library is space (Toda et al. (2007); Tella et al. (2009); Victor (2011); Michael et al. (2014)). It is often observed that the library inhabits the most desirable real estate on any college or university campus. Geographically and symbolically, it occupies the centre of a community established to support the advancement and perpetuation of knowledge. The positioning of the library conveys a sense of intellectual common ground, a setting in which knowledge from a range of disciplines comes together in a single place (Lonsdale (2003); Ekundayo (2013)). 


\section{Methods and Materials}

A categorical variable is one that has two or more categories, but there is no intrinsic ordering to the categories. The questionnaire for this study is in two sections. The first part consisted of 5 questions that relate to the demographic characteristics of the student's information which include the sex, age group, programmes, faculty, marital status and level while the section B consists of 26 questions. Most of the variables used for this study are categorical in nature.

Descriptive survey research was adopted for this study. The researchers used questionnaire for data collection. The population of this study consists of students from three (3) tertiary institutions and they are Ekiti State University, Federal Polytechnic AdoEkiti, and Federal University of Oye-Ekiti. Hundred (100) questionnaires were distributed to each school, making a sum of 300 questionnaires. Out of the three hundred (300) questionnaires that were randomly distributed for equal representation of each school across, two hundred and ninety-four (294) were returned in usable form representing 98\% responses; i.e. hundred (100) from Ekiti State University, ninety-eight (98) Federal Polytechnic Ado-Ekiti and ninety-six (96) from the Federal University of Oye Ekiti.

\section{Data Analysis and Interpretation}

The table below shows the demographic characteristics of the studied populations and discussion follows.

Table 1: Demographic Characteristics

\begin{tabular}{|c|c|c|c|c|c|}
\hline School & Demographic Characteristics & Response & $\mathbf{F}$ & Percent & Total \\
\hline $\begin{array}{l}\text { Ekiti State } \\
\text { University }\end{array}$ & \multirow{3}{*}{ Sex } & $\begin{array}{l}\text { Male } \\
\text { Female }\end{array}$ & $\begin{array}{l}45 \\
55\end{array}$ & $\begin{array}{l}15.3 \% \\
18.7 \%\end{array}$ & \multirow{3}{*}{$\begin{array}{c}294 \\
(100 \%)\end{array}$} \\
\hline $\begin{array}{l}\text { Fed. Polytechnic } \\
\text { Ado-Ekiti }\end{array}$ & & $\begin{array}{l}\text { Male } \\
\text { Female }\end{array}$ & $\begin{array}{l}62 \\
36 \\
\end{array}$ & $\begin{array}{l}21.1 \% \\
12.2 \% \\
\end{array}$ & \\
\hline $\begin{array}{l}\text { Fed. University } \\
\text { of Oye Ekiti }\end{array}$ & & $\begin{array}{l}\text { Male } \\
\text { Female }\end{array}$ & $\begin{array}{l}37 \\
59\end{array}$ & $\begin{array}{l}12.6 \% \\
20.1 \%\end{array}$ & \\
\hline $\begin{array}{l}\text { Ekiti State } \\
\text { University }\end{array}$ & \multirow{3}{*}{ Age } & $\begin{array}{l}0-20 \text { years } \\
21-30 \text { years } \\
31 \& \text { above }\end{array}$ & $\begin{array}{c}15 \\
83 \\
2 \\
\end{array}$ & $\begin{array}{c}5.1 \% \\
28.2 \% \\
0.7 \% \\
\end{array}$ & \multirow{3}{*}{$\begin{array}{c}294 \\
(100 \%)\end{array}$} \\
\hline $\begin{array}{l}\text { Federal Polytechnic } \\
\text { Ado-Ekiti }\end{array}$ & & $\begin{array}{l}0-20 \text { years } \\
21-30 \text { years } \\
31 \& \text { above }\end{array}$ & $\begin{array}{c}38 \\
56 \\
4 \\
\end{array}$ & $\begin{array}{c}12.9 \% \\
19.1 \% \\
1.4 \% \\
\end{array}$ & \\
\hline $\begin{array}{l}\text { Federal University } \\
\text { of Oye Ekiti }\end{array}$ & & $\begin{array}{l}0-20 \text { years } \\
21-30 \text { years } \\
31 \& \text { above }\end{array}$ & $\begin{array}{c}47 \\
48 \\
1 \\
\end{array}$ & $\begin{array}{c}16.0 \% \\
16.3 \% \\
0.3 \% \\
\end{array}$ & \\
\hline $\begin{array}{l}\text { Ekiti State } \\
\text { University }\end{array}$ & Level & $\begin{array}{l}100 \\
200 \\
300 \\
400 \& \text { above }\end{array}$ & $\begin{array}{c}5 \\
22 \\
22 \\
51\end{array}$ & $\begin{array}{c}1.7 \% \\
7.5 \% \\
7.5 \% \\
17.3 \%\end{array}$ & $\begin{array}{c}294 \\
(100 \%)\end{array}$ \\
\hline
\end{tabular}


PERFORMANCE OF STUDENTS IN EKITI STATE, NIGERIA

\begin{tabular}{|c|c|c|c|c|c|}
\hline $\begin{array}{l}\text { Federal Polytechnic } \\
\text { Ado-Ekiti }\end{array}$ & & $\begin{array}{l}100 \\
200 \\
300 \\
400 \& \text { above }\end{array}$ & $\begin{array}{c}57 \\
23 \\
7 \\
11\end{array}$ & $\begin{array}{l}19.4 \% \\
7.8 \% \\
2.4 \% \\
3.7 \%\end{array}$ & \\
\hline $\begin{array}{l}\text { Federal University } \\
\text { of Oye Ekiti }\end{array}$ & & $\begin{array}{l}100 \\
200 \\
300 \\
400 \& \text { above }\end{array}$ & $\begin{array}{c}71 \\
19 \\
6 \\
0\end{array}$ & $\begin{array}{c}24.1 \% \\
6.5 \% \\
2.0 \% \\
0 \%\end{array}$ & \\
\hline $\begin{array}{l}\text { Ekiti State } \\
\text { University }\end{array}$ & \multirow{3}{*}{ Programme } & $\begin{array}{l}\text { Part Time } \\
\text { Full Time } \\
\text { Others }\end{array}$ & $\begin{array}{c}5 \\
94 \\
1\end{array}$ & $\begin{array}{c}1.7 \% \\
32.0 \% \\
0.3 \%\end{array}$ & \multirow{3}{*}{$\begin{array}{c}294 \\
(100 \%)\end{array}$} \\
\hline $\begin{array}{l}\text { Federal Polytechnic } \\
\text { Ado-Ekiti }\end{array}$ & & $\begin{array}{l}\text { Part Time } \\
\text { Full Time } \\
\text { Others }\end{array}$ & $\begin{array}{c}1 \\
93 \\
4 \\
\end{array}$ & $\begin{array}{c}0.3 \% \\
31.6 \% \\
1.4 \% \\
\end{array}$ & \\
\hline $\begin{array}{l}\text { Federal University } \\
\text { of Oye Ekiti }\end{array}$ & & $\begin{array}{l}\text { Part Time } \\
\text { Full Time } \\
\text { Others }\end{array}$ & $\begin{array}{c}1 \\
93 \\
2\end{array}$ & $\begin{array}{c}0.3 \% \\
31.6 \% \\
0.7 \%\end{array}$ & \\
\hline
\end{tabular}

Table 2: Frequency Of Library Use by Students

\begin{tabular}{|l|c|c|c|c|}
\hline How often do you make use of the library? & EKSU & FEDPOLY & FUOYE & Total \\
\hline Daily & $5(5 \%)$ & $14(14.3 \%)$ & $8(8.3 \%)$ & $27(27.6 \%)$ \\
\hline Frequently & $8(8 \%)$ & $24(24.5 \%)$ & $17(17.7 \%)$ & $49(50.2)$ \\
\hline Rarely & $87(87 \%)$ & $59(60.2 \%)$ & $73(76 \%)$ & $21923.2 \%)$ \\
\hline
\end{tabular}

The result in Table 2 reveals that; in Ekiti State University, 5\% of the students do visit the library daily, $8 \%$ visit the library frequently and $87 \%$ rarely visit the library. This suggests that most of the students in Ekiti State University rarely visit the library. In Federal Polytechnic of Ado-Ekiti, $14.3 \%$ of the students do visit the library daily, $24.5 \%$ visit the library frequently and $60.2 \%$ rarely visit the library. This suggests that most of the students in Federal Polytechnic of Ado-Ekiti rarely visit the library. In Federal University Oye-Ekiti, $8.3 \%$ of the students do visit the library daily, $17.7 \%$ visit the library frequently and $76 \%$ rarely visit the library. This suggests that most of the students in Federal University Oye-Ekiti rarely visit the library.

Table 3: Result of Chi-Square Test on the use of library

\begin{tabular}{|l|c|c|c|}
\hline & Value & df & Asymp. Sig. (2-sided) \\
\hline Pearson Chi-Square & $18.674^{\mathrm{a}}$ & 6 & .005 \\
\hline Likelihood Ratio & 19.231 & 6 & .004 \\
\hline Linear-by-Linear Association & 1.190 & 1 & .275 \\
\hline N of Valid Cases & 294 & & \\
\hline
\end{tabular}

$\mathbf{H}_{0}$ : Use of the library is independent of the schools.

$\mathbf{H}_{1}$ : Use of the library is dependent on the schools. 
It can be seen that the test statistic value for Pearson Chi-Square is 18.674, with 6 degree of freedom, and as the $p$ value is smaller than 0.05 , we can conclude that there is a significantly difference of how often student's makes use of the library in each school.

Table 4: Symmetric measures

\begin{tabular}{|l|l|c|c|c|c|}
\hline \multicolumn{2}{|l|}{} & Value & $\begin{array}{c}\text { Asymp. Std. } \\
\text { Error }\end{array}$ & $\begin{array}{c}\text { Approx. } \\
\mathbf{T}^{\mathrm{b}}\end{array}$ & $\begin{array}{c}\text { Approx. } \\
\text { Sig. }\end{array}$ \\
\hline $\begin{array}{l}\text { Nominal by } \\
\text { Nominal }\end{array}$ & $\begin{array}{l}\text { Contingency } \\
\text { Coefficient }\end{array}$ & .246 & & & .005 \\
\hline Interval by Interval & Pearson's R & -.064 & .058 & -1.091 & $.276^{\mathrm{c}}$ \\
\hline N of Valid Cases & 294 & & & \\
\hline
\end{tabular}

From the table above, the Pearson's $\mathrm{R}$ having the approximately significance 0.276 which is greater than the $\mathrm{p}$ value 0.05 , we can conclude that there is no statistically significant and it is negatively correlated with the value -0.064 .

Table 5: Table showing comparison of the use of library and their cumulative grade point average (CGPA)

\begin{tabular}{|l|l|c|c|c|c|c|c|c|c|}
\hline $\begin{array}{l}\text { Do you make } \\
\text { use of the } \\
\text { library }\end{array}$ & \multicolumn{2}{|c|}{ EKSU } & \multicolumn{2}{c|}{ FEDPOLY } & \multicolumn{2}{c|}{ FUOYE } & \multicolumn{2}{c|}{ Total } \\
\cline { 2 - 9 } & Yes & No & Yes & No & Yes & No & Yes & No \\
\hline \multirow{5}{*}{ CGPA } & $0-$ & 8 & 12 & 9 & 1 & 7 & 1 & 16 & 14 \\
& 2.49 & $(8 \%)$ & $(12 \%)$ & $(9.2 \%)$ & $(1 \%)$ & $(7.3 \%)$ & $(1 \%)$ & $(24.5 \%)$ & $(14 \%)$ \\
\cline { 2 - 10 } & $2.50-$ & 28 & 22 & 31 & 15 & 24 & 9 & 83 & 46 \\
& 3.49 & $(28 \%)$ & $(22 \%)$ & $(31.6 \%)$ & $(15.3 \%)$ & $(25 \%)$ & $(9.4 \%)$ & $(84.6 \%)$ & $(46.7 \%)$ \\
\cline { 2 - 9 } & $3.50 \&$ & 16 & 14 & 30 & 12 & 38 & 17 & 84 & 43 \\
& above & $(16 \%)$ & $(14 \%)$ & $(30.6 \%)$ & $(12.2 \%)$ & $(39.6 \%)$ & $(17.7 \%)$ & $(85.2 \%)$ & $(43.9 \%)$ \\
\hline
\end{tabular}

Table 5 shows that 16 respondents (24.5\%) make use of the library while 14 respondents $(14 \%)$ did not make use of the library and have their CGPA between the range 0-2.49. 83 respondents $(84.6 \%)$ make use of the library and while 46 respondents $(46.7 \%)$ did not make use of the library and have their CGPA between the range 2.50-3.49. 84 respondents $(85.2 \%)$ made use of the library and while 43 respondents $(43.9 \%)$ did not make use of the library and had their CGPA between the range 3.50 and above.

Table 6: Chi-Square Tests of the use of Library and their CPGA

\begin{tabular}{|l|c|c|c|}
\hline & Value & df & Asymp. Sig. (2-sided) \\
\hline Pearson Chi-Square & $13.642^{\mathrm{a}}$ & 6 & .034 \\
\hline Likelihood Ratio & 14.222 & 6 & .027 \\
\hline Linear-by-Linear Association & 4.835 & 1 & .028 \\
\hline N of Valid Cases & 294 & & \\
\hline
\end{tabular}

$\mathbf{H}_{0}$ : There is no association between academic performance and the use of library. $\mathbf{H}_{1}$ : There is an association between academic performance and the use of library 
It can be seen that the test statistic value for Pearson Chi-Square is 13.642, with 6 degree of freedom, and as the $\mathrm{p}$ value (0.034) is smaller than 0.05 , we can conclude that there is an relationship between the use of library and the academic performance of students.

Table 7: Symmetric Measures

\begin{tabular}{|l|l|c|c|c|c|}
\hline \multicolumn{2}{|l|}{} & Value & $\begin{array}{c}\text { Asymp. Std. } \\
\text { Error }^{\mathbf{a}}\end{array}$ & $\begin{array}{c}\text { Approx. } \\
\mathbf{T}^{\mathbf{b}}\end{array}$ & $\begin{array}{c}\text { Approx. } \\
\text { Sig. }\end{array}$ \\
\hline Nominal by Nominal & Contingency Coefficient & .211 & & & .034 \\
\hline Interval by Interval & Pearson's R & -.128 & .063 & -2.213 & $.028^{c}$ \\
\hline N of Valid Cases & 294 & & & \\
\hline a. Not assuming the null hypothesis. \\
\hline b. Using the asymptotic standard error assuming the null hypothesis. \\
\hline c. Based on normal approximation.
\end{tabular}

From the table above, the Pearson's $\mathrm{R}$ having the approximately significance 0.028 which is less than the $\mathrm{p}$ value 0.05 , we can conclude that there is a statistically significant association between use of library and good performance.

\section{Discussion}

This research shows clearly that from the three tertiary Institutions libraries sampled, 27 respondents $(27.6 \%)$ of the 294 sample population confirmed that they make use of the library daily. On the other hand, 49 respondents (50.2\%) claimed that they make use of the library frequently, and 219 respondents agreed that they rarely make use of the library. Also using Chi-square and Pearson correlation, it is clear that there is statistical relationship in the use of library and the academic performance of students.

Also, that 16 respondents $(24.5 \%)$ made use of the library while 14 respondents $(14 \%)$ did not make use of the library and had their CGPA between the range 0-2.49. 83 respondents $(84.6 \%)$ made use of the library while 46 respondents $(46.7 \%)$ did not make use of the library and had their CGPA between the range 2.50-3.49. 84 respondents (85.2\%) made use of the library while 43 respondents $(43.9 \%)$ did not make use of the library and had their CGPAs between the range 3.50 and above.

Likewise, 209 respondents $(71.1 \%)$ confirmed that their school is residential and 85 respondents $(28.9 \%)$ disagreed that their school is residential. Also from the test carried out using chi-square, it is clear that there is statistical difference in the availability of school residence.

The study equally revealed that 244 respondents (83\%) claimed that their libraries are conducive for reading while 50 respondents $17 \%$ confirmed that their libraries are not conducive for reading. 


\section{Conclusion}

Considering the findings of this study, it can be concluded that the use of library has positive effect on the academic performance of students on their CGPAs in the three schools (Ekiti State University, Federal Polytechnic Ado-Ekiti, Federal University of OyeEkiti). The result shows that the school libraries are conducive for reading. The result also shows that Federal University is more residential and have the highest number of students with their CGPAs to be 3.50 and above. Since, a large percentage of students who have their CGPAs as 3.50 or above made use of the library, therefore, it can be safely concluded that there is a positive relationship between use of library and good grades.

\section{Conflict of Interest Statement}

The authors declare no conflicts of interests.

\section{About the Authors}

Olubiyi Adenike Olufunmilola is a Senior Lecturer in Ekiti State University, Nigeria. She has a PhD in Statistics from University of Ibadan. Her research interests are in Environmental Statistics and Statistics Education.

Babalola Bayowa Teniola is a Lecturer in Kampala International University, Uganda. He has a Master of Science in Statistics from Ekiti State University, Nigeria. His Area of research is Biostatistics and Statistics Education.

Fadugba Sunday Emmanuel is a Lecturer in Ekiti State University, Nigeria. He has a PhD in Mathematics. His research interests are in Financial Mathematics, Fractional Calculus, Numerical Analysis and Modelling.

\section{References}

Adeyemi T. O. (2010). The School Library and Students' Learning Outcomes in Secondary Schools in Ekiti State, Nigeria, Department of Educational Foundations and Management, University of Ado-Ekiti, P. M . B 5363, Ado-Ekiti, Nigeria.

Alan A. (2002). Categorical Data Analysis, Second Edition, Department of Statistics, University of Florida Gainesville, Florida.

Benbasat, I. (1984). An Analysis of Research Methodology. In F. Warren McFarlan (Ed.), Information systems research challenge (pp. 48-85). Boston, Massachusetts: Harvard Business school Press.

Budd, J. M. (1998). The academic library: Its context, its purpose and its operation. Englewood, Colorado: Libraries Unlimited.

Busayo I. O. (2014). Shelving, shelf reading and challenges of staff in academic libraries in Ekiti State. FUOYE Library, Federal University, Oye-Ekiti, Nigeria.

Ekundayo H. T. (2013). School facilities as correlates of students' achievement in the affective and psychomotor domains of learning, Department of Educational 
Foundations and Management, faculty of Education, Ekiti State University, AdoEkiti, Nigeria. European Scientific Journal March edition vol. 8, No.6 ISSN: 1857 7881 (Print) e - ISSN 1857- 7431.

Esse U. C. (2014). Effects of library instruction on satisfaction with the use of library and its services: A study of undergraduate students in five universities in the southern part of Nigeria. Covenant University, Ota, Nigeria. European Scientific Journal Vol. 10 No. 13 ISSN 1857-7881.

Jackson C. (2003). Categorical Data: Definition, Analysis and Examples, http://study.com/academy/lesson/categorical-data-definition-analysisexamples.html.

Lonsdale M. (2003). Impact of School Libraries on Student Achievement: a Review of the Research. Report for the Australian School Library Association, Australian Council for Educational Research (ACER) http://www.asla.org.au/site/defaultsite/filesystem/documents/research.pdf.

Michael J., Samuel O. O. and Peter O. O. (2014). Study habits, use of school libraries and students' academic performance in selected secondary schools in Ondo West Local Government Area of Ondo State, Adeyemi College of Education, Bab Fafunwa Library, P.M.B 520, Ondo, Ondo State, Nigeria.

Tella, Adeyinka; Owolabi, K. A.; \& Attama, R. O. (2009). Student use of the library: A case study at Akanu Ibiam Federal Polytechnic, Unwana, Nigeria. Chinese Librarianship: an International Electronic Journal, 28. URL: http://www.iclc.us/cliej/cl28TOA.pdf

Toda, A., Nagata, H., \& Kytomaki, P. (2007). Students' library use and their learning outcomes: A study on outcomes assessment in college and University library. Journal of the Japan Society of Library and Information Science, 53(1), 17-34.

Victor M. (2011). An analysis of some factors affecting student academic performance in an introductory biochemistry course at the University of the West Indies, Department of Food Production, Faculty of Science and Agriculture, The University of the West Indies, St. Augustine, Trinidad and Tobago. 
Olubiyi Adenike Olufunmilola, Babalola Bayowa Teniola, Fadugba Sunday Emmanuel STATISTICAL ANALYSIS OF THE EFFECT OF THE USE OF LIBRARY ON THE ACADEMIC PERFORMANCE OF STUDENTS IN EKITI STATE, NIGERIA

Creative Commons licensing terms

Authors will retain the copyright of their published articles agreeing that a Creative Commons Attribution 4.0 International License (CC BY 4.0) terms will be applied to their work. Under the terms of this license, no permission is required from the author(s) or publisher for members of the community to copy, distribute, transmit or adapt the article content, providing a proper, prominent and unambiguous attribution to the authors in a manner that makes clear that the materials are being reused under permission of a Creative Commons License. Views, opinions and conclusions expressed in this research article are views, opinions and conclusions of the author(s). Open Access Publishing Group and European Journal of Open Education and E-learning Studies shall not be responsible or answerable for any loss, damage or liability caused in relation to/arising out of conflict of interests, copyright violations and inappropriate or inaccurate use of any kind content related or integrated on the research work. All the published works are meeting the Open Access Publishing requirements and can be freely accessed, shared, modified, distributed and used in educational, commercial and non-commercial purposes under a Creative Commons Attribution 4.0 International License (CC BY 4.0). 